УДК 94(549.1)

\title{
ДИАСПОРА КАК ИНСТРУМЕНТ ПУБЛИЧНОЙ ДИПЛОМАТИИ ИНДИИ
}

Проблема миграции является актуальной во все времена. В данной статье предпринимается попытка рассмотреть истоки формирования индийской диаспоры и ее роль в процессе создания уникального имиджа страны за рубежом. Выступая в качестве одного из основных инструментов политики публичной дипломатии, диаспора позволяет разрешить недопонимания в межгосударственных отношениях, где одной из сторон выступает индийская республика, вносит существенный вклад в экономическое развитие, как Индии, так и страны проживания, а также является транслятором духовных ценностей в иностранную среду. Ввиду большой численности индийской диаспоры и для удобства сотрудничества диаспоры и Индии всех представителей принято делить на две группы в зависимости от наличия индийского гражданства и сроков пребывания за рубежом выделяют нерезидентов индийского происхождения и лица индийского происхождения. Получить данный статус, а соответственно и целый комплекс льгот (например, безвизовое посещение Индии), а также право участвовать в конкурсах, организуемых правительством Индии для ознакомления членов диаспоры с достижениями их родины, возможно при соответствии определенным критериям и предоставлению ряда документов в соответствующие учреждения. Значение индийской диаспоры для страны исследуется через призму лингвистического анализа некоторых дефиниций, обзора правительственных кампаний, направленных на установление и поддержание контактов с диаспорой, кинематографической продукции, а также произведений художественной литературы. Именно поэтому главным подходом данного исследования является междисциплинарность, что одновременно обусловливает как разносторонность исследования, так и сложность его осуществления.

Ключевые слова: диаспора, публичная дипломатия, Индия, лица индийского происхождения, нерезиденты индийского происхождения, индианизация.

\section{DIASPORA AS A TOOL OF INDIA'S PUBLIC DIPLOMACY}

The problem of migration is relevant at all times. This article attempts to consider the origins of the formation of the Indian diaspora and its role in the process of creating a unique image of the country abroad. Performing as one of the main policy instruments of public diplomacy, the diaspora allows to resolve misunderstandings in intergovernmental relations, where one of the sides is the Indian republic, makes a significant contribution to economic development, both in India and in the country of residence, and it is also a translator of spiritual values to foreign environment. Due to a big size of the Indian diaspora and for the convenience of cooperation between the diaspora and India, it is customary to divide all representatives into two groups depending on the availability of Indian citizenship and duration of stay abroad - non-residents of Indian origin and people of Indian origin are distinguished. It is possible to receive

Термин «диаспора» в переводе с древнегреческого означает «разбросать вокруг». В античности это понятие имело скорее позитивный смысл и подразумевало завоевание отдаленных берегов для родины, однако позже оно стало синонимом пленения и страданий. До конца XX века термин применялся в основном в отношении евреев-экспатриантов. В 60-90-е гг. XX века сложилась концепция классической или исторической диаспоры, куда помимо еврейской относили также such status, as well as a whole set of benefits (for example visa-free visits to India), as well as the right to participate in competitions organized by the Government of India to familiarize members of the diaspora with the achievements of their homeland, if they meet certain criteria and submit a number of documents to relevant institutions. The significance of the Indian diaspora for the country is explored through the prism of linguistic analysis of certain definitions a review of government campaigns aimed at establishing and maintaining contacts with the diaspora, cinematographic products, and works of fiction. That is why the main approach of this study is interdisciplinarity, which simultaneously determines both the versatility of the study and the complexity of its implementation.

Key words: diaspora, public diplomacy, India, persons of Indian origin, non-resident Indian, indianization.

армянскую и греческую диаспоры. А. Ашкенази Э. Скиннер и ряд других ученых к данной группе причисляли и индийскую [11]. Иными словами, это этнические меньшинства, сорормировавшиеся на территории иностранного государства по причине каких-либо неблагоприятных обстоятельств (попыток насильственного уничтожения, войн, депортаций и т.д.). В. Н. Шнирельман определяет мировоззрение представителей таких диаспор как «диаспоральный синдром» [13]. Со 
второй половины 90-х гг XX столетия формируется постклассическая модель понимания диаспоры, поскольку не все рассеянные по миру этнические меньшинства обладали признаками, присущими классическим, или «старым», диаспорам [1, л. 108].

Одна из серьезных попыток в изучении феномена диаспоры предпринимается в 1991 году профессором политологии университета Колорадо в Боулдере Уильямом Сафраном в рамках статьи «Диаспоры в современных обществах: мифы родины и возвращения». У. Сафран определяет диаспоры как «общины эмигрантов-меньшинств», которые можно охарактеризовать, используя следующие критерии [60]:

1) история расселения: народ рассеивается из исходного центра, по крайней мере, в две периферийные зоны;

2) мифы и воспоминания о родине: диаспоры хранят память, видение или мифы о своем первоначальном доме

3) отчуждение в принимающих странах: представители диаспоры полагают, что они не приняты полностью на новом месте;

4) стремление к возможному возвращению: диаспоры рассматривают родину как «место возращения» в подходящее время;

5) постоянная поддержка родины;

6) коллективная идентичность.

Другой известный исследователь глобализации, миграции и диаспоры, бывший директор Международного института миграции Оксорордского университета Робин Коэн, выделил девять критериев, характеризующих диаспоры, добавив: причины оттока из исходного места (поиски работы, с целью торговли или ввиду колониальных амбиций), возможности особой творческой активности в принимающих странах, а также чувство сопереживания и солидарности по отношению к членам диаспоры [27, р. 23-26]. Р. Коэн выделил следующие типы диаспор: диаспоры-жертвы, рабочие диаспоры, империалистические, торговые и культурные [2].

Американская писательница и историк Ким Бутлер в 2001 году сокращает список критериев до четырех:

1) диаспоры должны быть рассеяны как минимум в двух пунктах;

2) соотнесение к реальной или воображаемой родине

3) наличие самосознания у диаспоры;

4) существование диаспоры в рамках как минимум двух поколений [23, р.192].

Помимо этого, она вводит четыре измерения основ исследования диаспоры: причины и условия перемещения, отношения с родиной, отношения с принимающей стороной, и взаимосвязи в диаспоре [23, р. 194-209]

В отечественной научной литературе встречается множество определений диаспоры. Например, Ю. А. Поляков представляет довольно обобщенное понятие, определяя диаспору как этническую общность, находящуюся в иноэтничной среде, или же население той или иной стра- ны, принадлежащее этнически и культурно другому государству [10]. Так же универсализировано C. B. Лурье характеризует диаспору, как широкое понятие, включающее представителей другого народа, проживающего в чужом социокультурном окружении [3]. Придавая особое значение полной ассимиляции, 3. И. Левин определяет диаспору как часть этноса за пределами страны его происхождения и существующая лишь до тех пор, пока сохраняется ее этнокультурная специфика [9]. Более развернутый смысл в понятие вкладывает В. А. Колосов, понимая под диаспорой значительную часть этнической общности, живущей вне страны её происхождения и образующей давно сложившуюся, высокоорганизованную, сплоченную, устойчивую, хорошо укоренившуюся и ставшую необходимой для принимающей страны группу [5, л. 35]. Не менее детальное представление термина у И. В. Залитайло, рассматривающего под диаспорой устойчивую форму общности, образовавшуюся в результате миграций, проживающую локально или дисперсно вне исторической родины и имеющую способность к самоорганизации, представители которой объединены такими признаками, как групповое самосознание, память об историческом прошлом предков, культура народа [3, л. 105].

Таким образом, большинство исследователей едины во мнении, что диаспоры это этнические группы, рассредоточенные как минимум в двух центрах, имеющие самосознание и определенные представления о родине в зависимости от причин миграций.

В связи с многообразием причин и волн миграций в мировой истории, особенно сложным является проблема типологии диаспор. Наиболее целостная типология представлена в исследованиях Габриэля Шеффрера - авторитетного специалиста по диаспоре, профессора Еврейского университета в Иерусалиме. Г Шеффрер выделяет следующие диаспоры:

1) по наличию или отсутствию собственного государства («бездомные», «этнонациональные»);

2) по историческому опыту диаспоральности («старые», «молодые»)

3) в зависимости от стадии становления диаспоры: структурирование или фоормирование («зарождающиеся», «дремлющие»);

4) по географической протяженности диаспоральности («рассеянные», «компактные») [12, л. 167].

Г. Шеффер вводит понятие «детерриториализация родины», подразумевая процесс утраты родиной жестких пространственных, исторических координат; диаспоры, интегрируясь в новые социальные, культурные условия, связываются с ней протяженными и сложными сетями. Данные сети, пересекая границы государств, служат каналом коммуникации для удовлетворения социальных, культурных, образовательных, экономических, политических потребностей диаспор [12, л. $170-175]$

Изучение диаспор невозможно в рамках одной научной дисциплины, непременно происходит за- 
имствование научных подходов и принципов из различных систем знаний. К методологическим принципам в исспедовании современных диаспор относят:

1) конструктивизм, предполагающий интерпретацию диаспорной этничности в качестве одного из типов воображаемых сообществ, обладающих своими внутренними социальными связями, внешними границами, конструирующими образы «своих» и «чужих»;

2) антропоцентризм, согласно которому помещать в фокус анализа необходимо «этнический индивид ), а не монолитный коллектив;

3) институционализм, рассматривающий диаспоры как комплекс, прежде всего, социальных институтов, а не совокупность этнофоров в том или ином регионе;

4) наличие национальной государственности (современные диаспоры имеют за пределами страны проживания национальное государство или же претензии на его создание);

5) процессуальность, подразумевающая, что каждая диаспора имеет характер процесса воспроизводства идентичности и выстраивания связей;

6) стадиальность (выделяют стадии диаспоризации, дедиаспоризации - когда сообщество либо мигрирует на родину, либо ассимилируется, а также редиаспоризации - вторичного «пробуждения) идентичности);

7) многоуровневый характер идентичности, формирующийся в результате наслаивания социальной идентичности - приобретенной в принимающей стране на собственно этническую идентичность:

8) этнический дрейф, предусматривающий в случае многоуровневой идентичности совершение диаспорантом выбора в пользу одной из них;

9) двухуровневый характер связей;

10) включенность в транснациональные пространства;

11) стремление к посредничеству, обозначающее высокую степень подвижности, посредничество в социально-экономических, политических и культурных контактах в принимающей стране [2, л. 134].

Таким образом, несмотря на большое количество исследований, посвященных диаспоре, в науке все еще не сложился целостный подход к пониманию данной дефиниции и проблем, связанных с ее трактовкой и исследованием.

Историографию по проблемам индийской диаспоры условно можно разделить на четыре группы. К первой следует отнести общие труды, посвященные диаспоре, истории ее формирования, причинам миграций $[6,21,26,37,39,41,43,45,46$, $61,67]$. Ко второй - работы, построенные на географическом принципе изучения, рассматривающие индийскую диаспору и её вклад в развитие конкретных стран-рецепиентов $[7,17,19,20,25$, $34,39,52,53,62]$, к третьей - изучение отдельных этнических групп внутри полиэтничной индийской диаспоры (например, диаспору сикхов, телугу, тамилов, гуджаратцев и т.д.) $[16,22,29,32,35,36$,
$49,55,59,64]$. И, наконец, к четвертой - конкретные исследования, рассматривающие отдельные аспекты экономической, политической и духовной жизни диаспоры (например, роль женщин в диаспоре, кастовая система в среде индийских иммигрантов, развитие языка, литературы и науки посредством диаспоры и т.д.) $[14,19,29,39$ $42,48,51,57,58,63]$.

Особый интерес представляет собой диаспора в контексте ее использования в рамках политики публичной дипломатии. Будучи важнейшим фактором в формировании имиджа нации за рубежом, диаспоры рассматриваются правительствами стран происхождения как серьезный инструмент коммуникации с иностранной публикой.

Для достижения целей публичной дипломатии необходимо изучить настроение иностранного общественного мнения, а затем доносить свои идеи до тех, кто это мнение формирует (в литературе их нередко называют «stakeholders»). Диаспора в этом отношении уникальный ресурс, поскольку c ее помощью можно получить целостное представление об общественном мнении, настроении и ситуации в иностранном государстве, и ее же можно задействовать в процессе донесения своих идей и ценностных установокдо общественности данной страны.

Помимо этого, диаспора особо важна и с точки зрения отличий публичной дипломатии от пропаганды [8]. Так, если пропаганда преследует цель по максимуму привлечь и искусственно поддерживать число последователей, то целью публичной дипломатии является построение доверительных и долгосрочных отношений, а постоянно проживающая на территории иностранного государства диаспора способствует установлению надежных и продолжительных отношений. Если пропагандистская информация не всегда отличается правдивостью, то публичная дипломатия основывается на подлинных фактах, а степень доверия к реальным носителям определенных идей (коими являются члены диаспоры) естественно будет выше, чем к безымянным источникам информации. Пропаганда имеет одностороннюю направленность, а в нынешних условиях, позволяющих получателю самостоятельно фильтровать данные и критически к ним относиться, она и вовсе будет выглядеть как навязчивое информационное воздействие, тогда как публичная дипломатия предполагает диалог и обратную связь с аудиторией, учет ее интересов, с чем диаспора способна отлично справиться. В данном контексте срабатывает институциональный треугольник «страна происхождения - диаспора - страна пребывания», иллюстрирующий не только зависимость диаспоры от государств, но и зависимость страны (как родины, так и принимающей) от диаспоры

Вместе с тем, следует понимать, что если с одной стороны диаспоры оказывают помощь в реализации политики публичной дипломатии страны-происхождения, то оборотной стороной факта этнической рассеянности по миру будут являть- 
ся небезосновательные сомнения в отношении стабильности и наличия достойных условий для жизнедеятельности на родине диаспоры, особенно если речь идет о современных миграционных потоках, продиктованных, главным образом, социально-экономическими причинами. В свою очередь последнее может нанести ущерб имиджу стран-доноров. Следовательно, необходимо детально продумывать все шаги по использованию диаспоры как актора публичной дипломатии в деле создания привлекательного для иностранцев образа нации

Все множество конкретных причин миграций индийцев после обретения страной независимости можно разделить на две общие группы: внутренние и внешние. Внутренние связаны с резким ухудшением положения в стране, причем как в Индии (например, после событий 1984 года повлекших гонения на сикхов и заставивших многие семьи покинуть родину), так и в других странах с большой индийской диаспорой (взять хотя бы политику африканизации в странах Восточной Африки в конце 1960-начале 1970-х гг., вынудивших десятки тысяч индийцев искать убежище: или гражданскую войну на Шри-Ланке, в результате чего многие тамилы мигрировали в основном в Канаду, Данию, Норвегию и Швейцарию). В свою очередь, внешние причины сопряжены как правило, с изменениями в миграционных законодательствах «привлекательных» стран, упрощающих въезд с целью постоянного проживания на их территории (к примеру, завершение политики «Белой Австралии» вследствие подписания Миграционного Акта 1966 года, положившему конец ограничениям на въезд в страну по расовым признакам и др.).

По данным на 2015 год общая численность индийской диаспоры во всем мире оценивается в 27 млн человек, уступая лишь китайской [7, л. 161]

Для определения представителя индийской диаспоры используется термин «праваси» (pravasi), введенный в оборот в 1983 году [6, л. 62] Индийская диаспора состоит из двух категорий лиц: первая включает «лиц индийского происхождения) (РIO, Person of Indian Origin), то есть выходцев из Индии, в том числе колониальной (но за исключением территорий Пакистана и Бангладеш), не являющихся гражданами республики, а вторая - «нерезидентов индийского происхождения» (NRI, Non-Resident Indian) - индийцев, проживающих за пределами страны более 182 дней в году, $[7$, л. 176-177] но имеющие гражданство республики, либо двойное гражданство

Tермин NRI набирает большую популярность в 1980-е годы. Во многом это связано с приходом к власти Раджива Ганди в результате неожиданной смерти Индиры Ганди от рук телохранителей-сикхов в 1984 году. Будучи инженером по образованию, Р. Ганди уделял большое внимание технологическому развитию страны, в связи с чем в 1987 году назначил на должность Главного советника по вопросам технологий Сэма Питроду, нерезидента индийского происхождения, проживающего в США. Это ознаменовало триумфальное вхождение диаспоры в процесс модернизации страны и, как следствие, повлекло за собой инвестиции в индийскую экономику [47, р. 22]

Денежные переводы индийцев на родину составляют около 70 млрд долларов в год, что добавляет 3,5 \% к ВВП страны [7, л. 161]. Однако кроме экономической выгоды, диаспоры играют заметную роль и в политической сфере, как страны-пребывания, так и Индии, способствуя налаживанию дипломатических контактов и доверительных политических связей между странами. По словам бывшего министра иностранных дел Яшванта Синха, индийские американцы являются «чрезвычайно важными источниками поддержки индийского правительства в осуществлении своей политики через влияние и уважение, которыми они руководствуются» [33].

Действительно, если бы не диаспора было бы немыслимо заключение индо-американского соглашения о поставках в Индию ядерных топлива и технологий - «Закон Генри Дж. Хайда о мирном сотрудничестве США и Индии в области атомной энергии» [33]. То же самое можно сказать о снятии запрета на въезд в США Нарендры Моди в 2014 году (запрет был введен по обвинению в попустительстве погромов на мусульман в Гуджарате в 2002 году Нарендрой Моди, бывшим тогда министром штата). Самым же заметным событием программы пребывания Н. Моди в Нью-Йорке стало его выступление в знаменитом спортивно-концертном комплексе Madison Square Garden. Обращаясь к 18-тысячной аудитории индийской диаспоры в США, Н. Моди вещал с гигантской вращающейся платформы, говоря на хинди [4].

Индийская диаспора в США насчитывает более 4 млн человек [64]. Помимо численности как одну из самых влиятельных общин в США индийскую диаспору характеризуют следующие факторы: во-первых, примерно $90 \%$ индийцев в США участвуют в выборах и являются политически активными; во-вторых, они имеют самые высокие доходы (начиная с 1970-х гг.), по сравнению с другими диаспорами в США, следовательно, стремятся перевести данный финансовый потенциал в политическое влияние; 15 \% фирм Кремниевой долины принадлежит индийцам; 200 тыс. индийцев в США - миллионеры; 43,6\% индийцев работают на высоких должностях [34, p. 3-4], особо влиятельна Американская ассоциация врачей индийского происхождения (American Association of Physicians of Indian origin, AAPI), насчитывающая 80 тыс. специалистов [15]; 77\% индийцев старше 25 лет имеют степень бакалавра, а больше половины из них - степени магистра и кандидата наук [65].

Другим не менее значимым центром притяжения выходцев из Индии является Великобритания. Из-за многочисленной диаспоры (1.5 млн человек [7, л. 161]) в этом государстве, все чаще используют выражение "обратная колонизация". Хотя можно назвать немало представителей юж- 
ноазиатских диаспор, добившихся значительных успехов в Соединенном Королевстве, однако ни одна диаспора по показателям восходящей социальной мобильности и влиятельности не может сравниться с индийской. В рейтингах наиболее богатых и успешных подданных британской короны уже многие годы фигурируют индийцы (Р. Сингх, Л. Митал, П. Лохиа, М. Мандавани, Г. Лалвани и многие другие), а по оценкам исследователей ежегодный вклад диаспоры в формирование ВВП страны составляет около $10 \%$. В обеих палатах британского парламента заседают лица индийского происхождения. Апогеем индо-британского сотрудничества стала громкая сделка по выкупу автомобильной компаний Jaguar Land Rover в 2008 году индийским конгломератом Tata Industries за 1,15 млрд фунтов стерлингов [7, л. 168-179]. Аналогичная модель развития индийской диаспоры наблюдается в Канаде, где более 1,4 млн человек - лица индийского происхождения, в том числе и Министр национальной обороны Харджит Сингх Саджан; в Сингапуре, Австралии и ряде стран Европы.

Диаспора рассматривается индийским правительством как важнейший ресурс, что подтверждается целым рядом фактов

В 2000 году МИД Индии учреждает Комитет высокого уровня по делам индийской диаспоры (High Level Committee on Indian Diaspora) под председательством Л. М. Сингхви - бывшего индийского посла в Великобритании. Задачей Комитета становится подготовка доклада о положении диаспоры в различных странах. Доклад был представлен в 2002 году премьер-министру А. Б. Ваджпаи. Он является первым масштабным исследованием диаспоры, заказанным правительством страны.

Начиная с 2003 года, ежегодно 9 января в стране празднуется день диаспоры - Праваси Бхаратия Дивас (Pravasi Bharatiya Divas). Дата выбрана не случайно, 9 января 1915 года Махатма Ганди вернулся из Южной Африки в Индию [47, р. 24]. Официальная цель празднования - сохранение памяти о милостях и вкладе индийцев-нерезидентов в благосостояние и развитие нации. В рамках празднования происходит церемония награждения представителей диаспоры за их вклад в процветание родины - Праваси Бхаратия Самман (Pravasi Bharatiya Samman), в рамках которой президент Индии вручает почетные награды.

Вклад может быть, в том числе, и не материальным, например, за усилия по продвижению индийских языков и культуры. Так, премьер-министр А. Б. Ваджпаи, выступив на первой конференции, посвященной дню диаспоры, отметил: «Многие из вас или ваши предки покинули Индию в поисках счастья или лучшей доли. Сегодня сама Индия стала территорией возможностей. Мы хотим поделиться с нашей обширной семьей нашими достижениями, надеждами, заботами, планами и целями... Мы приглашаем вас не только разделить с нами наше представление об Индии в новом тысячелетии, но и помочь нам сформировать его очертания. Мы не хотим только лишь ваших инвестиций. Мы хотим услышать ваши идеи. Нам не нужны ваши богатства, нам нужно богатство вашего опыта» [7, л. 178]

В мае 2004 года учреждается Министерство по делам индийцев, проживающих за рубежом (MOIA, Ministry of Overseas Indian Affairs). В 2016 году оно упраздняется, а его руководитель Сушма Сварадж - становится главой Министерства иностранных дел страны. Тем не менее, за более чем 10 лет автономного функционирования министерства было проведено множество кампаний по укреплению связей с диаспорой (например, программа «Отслеживание корней» (Tracing Roots), позволяющая лицам индийского происхождения подать заявку с целью получения информации об их предках; или стипендиальная программа для детей диаспоры, позволившая детям зарубежного сообщества Индии претендовать на получение стипендий для обучения на исторической родине по целому ряду направлений; с 2014 года реализуется программа «Знай Индию» (Know India Programme, KIP [46]), в coответствии с которой ежегодно молодежь от 18 до 26 лет из более чем 30 стран диаспоры приглашают на три недели в республику для знакомства с исторической родиной).

Большое внимание Министерство по делам индийцев уделяло трудовым эмигрантам. С этой целью создается Совет по содействию занятости за рубежом, переименованный в Индийский совет по занятости за рубежом (Indian Council for Overseas Employment, ICOE), выступающий в качестве мозгового центра проведения исспедований рынка, определения возможностей трудоустройства за рубежом, развития навыков, соответствующих рыночному спросу, разработки стратегий реагирования на динамичный международный рынок труда и т.д. Были образованы зарубежные индийские центры (Overseas Indian Centres) для предоставления медицинских, юридических и финансовых консультаций рабочим индийского происхождения. Для предотвращения проблем, с которыми могут столкнуться индийские рабочие, а также их социальной защиты в стране пребывания подписывается ряд двусторонних соглашений с различными странами, включая Францию, Германию, а также государства Персидского залива. С целью повышения уровня квалификации потенциальных эмигрантов в соответствие с требованиями зарубежного рынка труда и предоставления им базовых знаний о законах, языке и культуре страны назначения, в 2006-2007 г. разрабатывается «Схема повышения квалификации для потенциальных эмигрантов».

С 2003 года действует «Pravasi Bharatiya Bima Yojana» (PBBY) - это схема обязательного страхования, направленная на защиту интересов индийских рабочих-эмигрантов, подпадающих под категорию «Требуется проверка на эмиграцию» (Emigration Check Required, ECR), выезжающих на работу в страны ECR (Афганистан, государства Юго-Восточной Азии, Ближнего Востока и 
Восточной Африки). Схема подвергалась изменениям в 2006, 2008 и 2017 годах с целью расширения охвата рабочих-эмигрантов.

В 2005 году вводится система иностранного гражданства Индии (OCl, Overseas Citizenship of India [55]). Иностранные граждане индийского происхождения могут получить карту иностранного гражданина при соответствии списку критериев (например, не допускается выдача карты лицам, проживающим на территории Пакистана или Бангладеш, а также тем, чьи предки были гражданами этих государств). Обладателям карт предоставляется целый ряд привилегий, в частности пожизненное безвизовое посещение Индии. Однако в отличие от нерезидентов индийского происхождения, держатели данных карт не имеют политических прав, поэтому данный статус не следует истолковывать как «двойное гражданство».

В январе 2019 год премьер-министр Нарендра Моди разворачивает кампанию под названием «Pravasi Teerth Darshan Yojana) (Инициатива паломничества диаспоры). Правительство страны дважды в год будет спонсировать туры по Индии лицам индийского происхождения, проживающих за рубежом в возрасте от 45 до 65 лет. Льготь получат выходцы из так называемых «Gimritiyacountries») ${ }^{1}$ (Фиджи, Суринам, Маврикий, Ямайка, Тринидад и Тобаго и др.), то есть потомки индийских рабочих, завезенных сюда во второй половине XIX века для работы на плантациях сахарного тростника (в историографии их также называют «старой» диаспорой в противовес «новой», проживающей на территории Европы, США, Австралии и Канады [50, р. 236]). Первая группа, численностью в 40 человек уже совершила тур [56].

Совершенно очевидно, что правительство республики заинтересовано в формировании у этнических индийцев позитивного образа исторической родины. Создаются условия, как для репатриации, так и для повышения имиджа нации на международной арене через эмигрантов. Индия всеми силами старается продемонстрировать миру свои прогрессивные характеристики, в том числе воздействуя на диаспору эмоционально посредством средств массовой культуры, в частности фильмов, являющихся важным ресурсом индийской мягкой силы.

Довольно любопытной представляется статья Чандримы Чакраборти, рассматривающая стыд в кинематографе (на примере фильма «Возвращение на родину» (Swades, 2004, режиссер: Ашутош Говарикер) как средство переориентации индийской диаспоры на страну происхождения, с целью увеличения инвестиций в республику или, еще лучше, возвращения на родину [24].

Виджай Мишра - профессор английской и сравнительной литературы в Университете Мердока (Перт, Австралия) в своих работах доказывает, что Болливуд всегда способствовал формированию и распространению образа воображаемой

Здесь: Girmit - слово на языке Авадхи, обозначающее соглашение (имеется ввиду между Британской Империей и рядом стран-колоний). Термин был введен М. Ганди, назвавшим себя первым Girmitiya. родины и ее идеализации, поскольку диаспоры представляют собой широчайший рынок потребителей продукции индийской кинопромышленности $[50$, р. 296]. Так, индийское правительство проводит последовательную политику, добиваясь если и не возвращения членов диаспоры на историческую родину, то формирования положительного к ней отношения и, как следствие, распространения этих позитивных оценок в среде иностранной публики.

Однако диаспоре не всегда придавалась такая значимость в индийском обществе. Тот же кинематограф позволяет проследить эволюцию отношения к иностранным индийцам и задаться вопросом о причинах трансорормации с негативной оценки поведения членов диаспоры до абсолютно позитивной. Первые фильмы, рассказывающие о жизни индийцев, покинувших родину, изображают их совершенно безнравственными, ставится под сомнение их принадлежность к индийской культуpe («Восток и Запад)/Purab Aur Paschim, режиссера Маноджа Кумара, 1970 года и др.). Вплоть до 1990-х гг. иностранный индиец был абсолютным антигероем, чье спасение заключалось в драматическом изменении статуса [66].

Пока эмиграция несла печать морального позора, такие выдающиеся экономисты, как Джагдиш Бхагвати старались изо всех сил оценить реальную стоимость утечки умов, чтобы взимать налог с индусов-экспатриантов. Он предложил распространить юрисдикцию подоходного налога на граждан-эмигрантов, считая, что гражданство налагает на них налоговые обязательства. Идея «налога Бхагвати» нередко привлекает к себе внимание в контексте поиска решения проблемы «утечки мозгов» из беднейших стран мира [29].

С 1990-х годов начинается «золотой век» индийской диаспоры, что напрямую связано с зарождением среднего класса и новых материальных устремлений Индии в разгар экономической либерализации. С середины 1990-х годов в индийской кинопродукции все чаще центральной идеей становится упрек с намерением пристыдить персонажа-эмигранта (обязательно успешно себя реализовавшего за рубежом) и критически относящегося к родине (например, Раджа из «Непохищенной невесты» (Dilwale Dulhania Le Jayenge, Адитья Чопра, 1995) или Раджива из фильма «На чужбине» (Pardes, Субхаш Гхай, 1997)), с целью вернуть его к исконной культурной идентичности. Используя ностальгию по потерянной родине, в таких фильмах обязательно присутствует антагонист, ему, несмотря на то, что он проживает вдали от родины, удается сохранить культуру, ценности и традиции своего народа. Эти фильмы не изображают членов диаспоры безнравственными, а наоборот стремятся показать, чем на практике они могут быть полезны для своей родины вместо пустословной критики. Теперь индийские эмигранты представляют собой удивительный синтез современности и традиций, патриотизма свадеши ${ }^{2}$ и англосаксонского капитализма.

2 Здесь: движение за независимость и самостоятельность Индии. 
Так, всемирно известный режиссер, продюсер и сценарист Яш Чопра - основатель крупнейшей в Индии кинокомпании Yash Raj Films - во время своего выступления на праздновании Дня диаспоры в 2003 году заявил, что «наша моральная ответственность заключается в том, чтобы изображать Индию в лучшем виде. Мы историки Индии (...). Индийская диаспора должна сохранять свою самобытность, свои корни [66]».

Изменение в положительную сторону к эмигрантам подтверждает и лингвистический анализ. В 1990-е гг. термин «вилаят» (vilayat) уступает место слову «пардес» (pardes) для обозначения места жительства заграничных индийцев. Вилайат, персидское слово, образованное от арабского «вилайя» т.е. «провинция», использовалось в колониальную эпоху для обозначения территорий за пределами Индии, и всегда ассоциировалось с безнравственностью. Слово «пардес» индийского происхождения, в переводе означает «чужая страна» и несет в себе гораздо больше позитивного смысла, в отличие от «вилайат» [66].

Помимо фильмов, диаспора нередко становится основной темой и в произведениях художественной литературы таких успешных современных писателей индийского происхождения, как Киран Десаи («Наследство разоренных»), Читра Банерджи Дивакаруни («Хозяйка специй), "Сестра моего сердца»), Анош Ирани (пьесы: «Люди в белом», «Моя бабушка Золотая рыбка»), Салман Рушди («Сатанинские стихи»), лауреат Нобелевской премии по литературе в 2001 году Видьядхар Сураджпрасад Найпол («Мистик-массажист», «Мигель-стрит», «Дом для мистера Бисваса»), а также иностранного происхождения: Марк Леви («Не такая, как все»), Ричард Морисон («Путь длиной в сто шагов») и др.

Идентичность в каждом из произведений понимается по-своему, в некоторых книгах прослеживается критика и отказ возвращаться на родину, в некоторых - наоборот: многое зависит от реальной судьбы самого автора. Если британский писатель индийского происхождения В. С. Найпол в «Доме для мистера Бисваса» пишет об индо-тринидадцах, что «они постоянно говорили о возвращении в Индию, но когда возникала такая возможность, многие отказывались, пугаясь неиз- вестности, боясь лишиться уже привычной временности своего здесь пребывания $[8$, л. 67]», то канадский драматург А. Ирани в одном из своих интервью отметил: «Когда я приехал в Канаду, я понял, как сильно я жаждал Бомбея, как сильно я жаждал Индии. И я думаю, что боль - это желание быть там снова - заставила меня писать (...) Ванкувер, безусловно, мой дом, и я очень горжусь тем, что нахожусь в Канаде, но и Индия моя муза. Она отличный учитель. Поэтому у меня нет оснований что-либо отрезать: оба места обогащают меня как человека и как писателя [31]»

Таким образом, индийская диаспора является важнейшим инструментом разрешения многих проблем страны, борьбы с различными негативными стереотипами об индийской культуре и создания имиджа великой, бурной развивающейся и талантливой нации. Изменения в системе международных отношений, согласно чему авторитет страны на мировой арене обуславливается не только военно-экономическими показателями, но и потенциалом мягкой силы приводит индийское правительство к пониманию важности диаспоры для достижения своих целей, главным образом, формирования максимально привлекательного образа страны за рубежом. Будучи ядерной державой, но не присоединившейся к договору о нераспространении, Индии очень важно сохранять имидж миролюбивой, способной к диалогу (нередко посредством членов диаспоры), нации. Индийская диаспора позволяет решить данные задачи, привлекая как непосредственно, так и косвенно инвестиции в республику.

Вся суть взаимодействия диаспоры со страной происхождения и пребывания отражается в термине «индианизация». Поразительно, но индийской диаспоре удается благополучно интегрируясь в политическую, социальную и экономическую подсистемы зарубежного общества, сохранять собственную культурную идентичность и проповедовать свои ценности как когда-то Вивекананда, вызывая неподдельный интерес к собственной родине. Прослеживается прямая зависимость от степени успешной интеграции диаспоры в общество иностранного государства со степенью развития тесных взаимоотношений между Индией и этими странами.

\section{Источники и литература}

1. Авдашкин А. А. Диаспора: происхождение и развитие понятия // Социум и власть. 2013. №2 (40). С. 107-111.

2. Авдашкин А. А. Феномен диаспоры: методологические основы научного исследования // Вестник Челябинского государственного университета. 2015. №2 (357). Вып. 62. С. 131-37.

3. Еханурова И. Р. Теоретические подходы к определению понятия «диаспора» // Вестник Бурятского университета. 2011. № 6. С. 104-107.

4. Индийский премьер заклинает Америку. Нарендра Моди получил въездную визу в США и налаживает партнерство // Коммерсантъ. 2014. №177. URL: https://www.kommersant.ru/doc/2579123 (Дата обращения: 09.05.2019).

5. Колосов В. А., Галкина Т. А., Куйбышев М. В. География диаспор на территории бывшего СССР // Общественные науки и современность. 1996. № 5. С. 34-46.

6. Котин И. Ю. Голос индийской диаспоры // Вестник СпбГУ. 2009. Сер. 13. Вып. 4. С. 62-71

7. Кулик Л. В. Индийская диаспора в Великобритании // Вестник МГИМО-Университета. 2017. № 2(53). С. 160-183

8. Лебедева М. М. «Мягкая сила»: понятие и подходы // Вестник МГИМО Университета. 2017. №3(54). С. 212-223.

9. Левин 3. И. Менталитет диаспоры: системный и социокультурный анализ. М.: Крафт+, 2001. 176 с.

10. Национальные диаспоры в России и за рубежом в XIX-XX вв.: Сб. ст. Рос. акад. наук. Ин-т рос. Истории / сост Г. Я. Тарле. М.: Ин-т рос. истории РАН, 2001. 330 с. 
11. Попков В. Д. «Классические диаспоры»: к вопросу о дефиниции термина // Диаспоры. 2002. №1. С. 6-23.

12. Шеффер Г. Диаспоры в мировой политике // Диаспоры. 2003. №1. С. 162-184.

13. Шнирельман В. Н. Мифы диаспоры // Диаспоры. №1. 2003. С. 162-185.

14. Abraham M. Speaking the Unspeakable: Marital Violence among South Asian Immigrants in the United States. Princeton: Rutgers University Press, 2000. 264 p.

15. American Association of Physicians of Indian Origin (Official website). URL: https://www.aapiusa org/about-us/aboutаарі/ (Дата обращения: 09.05.2019).

16. Angelo M. The Sikh Diaspora: Tradition and Change in an Immigrant Community. New York: Routledge, 2013. 342 p.

17. Arasaratnam S. Indians in Malaysia and Singapore. London: Oxford University Press for the Institute of Race Relations, 1970. 214 p.

18. Arkin A. J. The Contribution of Indians in the South African Economy, 1860-1970. Durban: Institute for Social and Economic Research, University of Durban-Westville, 1981. 358 p.

19. Assayag J., Benei V. At Home in Diaspora: South Asian Scholars and the West. New Delhi: Permanent Black, 2003 $207 p$

20. Azuma M. Sikh Diaspora in Japan. Routledge, 2018. 174 p.

21. Baumann M. Conceptualising Diaspora: The Preservation of Religious Identity in Foreign Parts, Exemplified by Hindu Communities Outside India // Temenos: Nordic Journal of Comparative Religion. 2012. Vol. 31. P. 19-35.

22. Bhachu P. The East African Sikh Diaspora: The British Case // Aspects of the South Asian Diaspora. New Delhi: Oxford University Press, 1991. P. 57-85.

23. Butler K. D. Defining Diaspora, Refining a Discourse // In Diaspora. 2001. Vol. 10. №2. P. 189-219

24. Chakraborty C. Shaming the Indian Diaspora, Asking for «Returns»: Swades // TOPIA: Canadian Journal of Cultural Studies, 2011. Vol. 26. P. 11-28.

25. Chakravarti N. R. The Indian Minority in Burma: The Rise and Decline of an Immigrant Community. London: Oxford University Press for the Institute of Race Relations, 1971.214 p.

26. Clarke C. South Asians overseas: migration and ethnicity. Cambridge: Cambridge University Press, 2010. 396 p.

27. Cohen R. Global Diasporas: An Introduction. London: Routledge, 2008. 240 p.

28. Dasgupta S. D. A Patchwork Shawl: Chronicles of South Asian Women in America. New Brunswick: Rutgers University Press, 1998. $239 \mathrm{p}$.

29. Dumitru S. Skilled Migration: Who Should Pay for What? A Critique of the Bhagwati Tax // Diversities. 2012. Vol. 14 № 1. Pp. 8-23.

30. Dusenbery V. A. A Sikh Diaspora // Nationand migration: the politics of space in the South Asian Diaspora. Philadelphia: University of Pennsylvania Press, 1995. P. 17-42

31. Fond Indian memories feed Anosh Irani's My Granny the Goldfish // The Georgia Straight. Vancouver, 2010. URL: https:// www.straight.com/article-318887/vancouver/fond-indian-memories-feed-iranis-goldfish (Дата обращения: 20.05.2019).

32. Fuglerud Q. Life on the Outside: The Tamil Diaspora and Long-distance Nationalism. London: Pluto Press, 1999. 203 p

33. Gottschlich P. The Indian Diaspora in the United States of America: An Emerging Political Force? // Indian Diaspora: Retrospect and Prospect. New Delhi: Sage Publications, 2006. URL: https://sk.sagepub.com/books/tracing-an-indiandiaspora/n9.xml (Accessed: 12.05.2019).

34. Gupta A. The Indian Diaspora's Political Efforts in the United States // Observer Research Foundation. New Delhi, 2004. P. $1-21$

35. Hawley M. Sikh Diaspora: Theory, Agency, and Experience (collection of essays). Calgary: BRILL, 2013. $438 p$

36. Helweg A. W. Sikhs in England: the development of a migrant community. Delhi: Oxford University Press, 1987. $282 p$

37. Jain P. C. Indians Abroad: A Current Population Estimate // Economic and Political Weekly. Vol.17. № 8. P. $299-304$.

38. Jain P. C. Indians in South Africa: Political Economy of Race Relations. New Delhi: Kalinga Publications, 1999. 175 p

39. Jain R. K. Indian Communities Abroad: themes and literature. New Delhi: Manohar Publishers \& Distributors, 1993. $90 \mathrm{p}$

40. Jayaram N. The Dynamics of Language in Indian Diaspora // The Indian Diaspora: Dynamics of Migration, 2000.

P. 147-171.

41. Jayaram N. The Indian Diaspora: Dynamics of Migration. Delhi: Sage Publications, 2004. 255 p.

42. Jayaram N. The Metamorphosis of Caste Among Trinidad Hindus // Contributions to Indian Sociology. 2006.40 (2)

P. $143-173$

43. Khadria B. India Migration Report 2009: Past, Present, and the Future Outlook. International Migration and Diaspora

Studies Project, Zakir Hussain Centre for Educational Studies. New Delhi: Jawaharlal Nehru University, 2009. 147 p

44. Know India Programme (Official website). URL: https://knowindia.gov.in/ (Accessed: 10.05.2019).

45. Kondapi C. Indians Overseas: 1838-1949. Madras: Oxford University Press, 1951.550 p.

46. Lal B. V., Reeves P., Rai R. The encyclopedia of the Indian Diaspora. Honolulu: University of Hawai i Press, 2007. $416 \mathrm{p}$

47. Lal V. India in the World: Hinduism, the Diaspora, and the Anxiety of Influence // Australian Religion Studies Review 2003. Vol.16. №2. P. 19-37.

48. Lemon A. The political position of Indians in South Africa // South Asians overseas: migration and ethnicity. 1990

P. $131-163$

49. Leonard K. I. Locating Home: India's Hyderabadis Abroad. Redwood City: Stanford University Press, 2007. 402 p.

50. Mishra V. Bollywood Cinema: Temples of Desire. London: Routledge, 2002. 296 p.

51. Mishra V. The Literature of the Indian Diaspora: Theorizing the Diasporic Imaginary. New Delhi: Routledge, 2007. $313 \mathrm{p}$

52. Morris H. S. The Indians in Uganda. Chicago: University of Chicago Press, 1968. $230 \mathrm{p}$.

53. Nath D. A History of Indians in Guyana. London: Published by the Author, 1970. 281 p.

54. Nayar K.E. The Sikh Diaspora in Vancouver: Three Generations Amid Tradition, Modernity, and Multiculturalism Toronto: University of Toronto Press, 2004. 276 p. 
55. Overseas Citizenship of India (Online OCI Services). URL: https://ociservices.gov.in/ (Accessed: 12.05.2019). 56. PM launches Pravasi Teerth Darshan Yojana // The Times of India, (Jan 22, 2019). URL: https://timesofindia.indiatimes. com/india/pm-launches-pravasi-teerth-darshan-yojana/articleshow/67647538.cms (Accessed: 15.05.2019)

57. Puwar N., Raghuram P. (eds). South Asian Women in the Diaspora. New York: Berg, 2003. 264 p.

58. Rayaprol A. Negotiating Identities: Women in the Indian Diaspora. New Delhi: Oxford University Press, 1997.165 .

59. Reddy P. C. Telugu Diaspora Through the Ages: From the Earliest Times. New Delhi: B.R. Publishing Corporation, 2017. $350 \mathrm{p}$.

60. Safran W. Diasporas in Modern Societies: Myths of Homeland and Return // In Diaspora. 1991. Vol.1. №1. P. 83-99

61. Safran W., Sahoo A., Lal B. V. Transnational Migrations: The Indian Diaspora. New Delhi: Routledge, 2013.211 p.

62. Sahay A. Indian Diaspora in the United States: Brain Drain Or Gain? Lanham: Lexington Books, 2009.262 p.

63. Speckmann J. D. Marriage and Kinship Among the Indians in Surinam. Assen: Van Gorcum\&Co, 1965. 302 p.

64. Tatla D. S. The Sikh Diaspora. The Search for Statehood. London: UCL Press Limited, 2005. 293 p.

65. The Role of the Diaspora (A report to the Australian Government by Mr. Peter N. Varghese AO) // India Economic Strategy to 2035. URL: https://dfat.gov.au/geo/india/ies/chapter-18.html (Accessed: 09.05.2019).

66. Therwath I. «Shining Indians»: Diaspora and Exemplarity in Bollywood // South Asia Multidisciplinary Academic Journal 2010. URL: http://journals.openedition.org/samaj/3000 (Accessed: 20.05.2019).

67. Vertovec S. The Hindu Diaspora: Comparative Patterns. New Delhi: Routledge, 2013. 208 p

\section{References}

1. Avdashkin A.A. Diaspora: proiskhozhdenie i razvitie ponyatiya (Diaspora: the origin and development of the concept) /I Sotsium i vlast'. 2013. No.2 (40). P. 107-111. (In Russian).

2. Avdashkin A. A. Fenomen diaspory: metodologicheskie osnovy nauchnogo issledovaniya (The phenomenon of the diaspora: methodological basics of scientific research) // Vestnik Chelyabinskogo gosudarstvennogo universiteta. 2015 . No. 2 (357). Issue. 62. P. 131-37. (In Russian).

3. Ekhanurova I. R. Teoreticheskie podkhody k opredeleniyu ponyatiya «diaspora» (Theoretical approaches to the definition of the term «diaspora») // Vestnik Buryatskogo universiteta. 2011. No. 6. P. 104-107. (In Russian).

4. Indiiskii prem'er zaklinaet Ameriku. Narendra Modi poluchil v»ezdnuyu vizu v SShA i nalazhivaet partnerstvo (The Indian prime minister conjures America. Narendra Modi received an entry visa to the United States and establishes a partnership) /I Kommersant. 2014. No.177. URL: https://www.kommersant.ru/doc/2579123 (Accessed: 09.05.2019). Accessed

5. Kolosov V. A., Galkina T. A., Kuibyshev M. V. Geografiya diaspor na territorii byvshego SSSR (The geography of diasporas in the territory of the former USSR) // Obshchestvennye nauki i sovremennost'. 1996. No. 5. P. 34-46.

6. Kotin I. Yu. Golos indiiskoi diaspory (The voice of the Indian diaspora) // Vestnik SpbGU. 2009. Seria. 13. Issue. 4. P. 6271. Accessed

7. Kulik L. V. Indiiskaya diaspora v Velikobritanii (Indian diaspora in the UK) // Vestnik MGIMO-Universiteta. 2017. No. 2(53) P. 160-183. Accessed

8. Lebedeva M. M. «Myagkaya sila»: ponyatie i podkhody («Soft power»: concept and approaches) // Vestnik MGIMO Universiteta. 2017. No. 3 (54). P. 212-223. Accessed

9. Levin Z. I. Mentalitet diaspory: sistemnyi i sotsiokul'turnyi analiz (Diaspora mentality: systemic and sociocultural analysis). Moscow: Kraft+, 2001. 176 p. Accessed

10. Natsional'nye diaspory $v$ Rossii i za rubezhom v XIX-XX vv. (National diasporas in Russia and abroad in the XIX-XX centuries.) (Sb. st. Ros. akad. nauk. In-t ros. istorii. Sost. G. Ya. Tarle). Moscow: In-t ros. istorii RAN, 2001. 330 p. Accessed

11. Popkov V. D. "Klassicheskie diaspory»: k voprosu o definitsii termina ("Classical diasporas»: on the definition of the term) // Diaspory. 2002. No. 1. P. 6-23. Accessed

12. Sheffer G. Diaspory v mirovoi politike (Diaspora in world politics) // Diaspory. 2003. No.1. P. 162-184. Accessed

13. Shnirel'man V. N. Mify diaspory (Diaspora myths) // Diaspory. No. 1. 2003. P. 162-185. Accessed

14. Abraham M. Speaking the Unspeakable: Marital Violence among South Asian Immigrants in the United States Princeton: Rutgers University Press, 2000. 264 p.

15. American Association of Physicians of Indian Origin (Official website). URL: https:/www.aapiusa.org/about-us/aboutaapi/ (Accessed: 09.05.2019).

16. Angelo M. The Sikh Diaspora: Tradition and Change in an Immigrant Community. New York: Routledge, $2013.342 \mathrm{p}$.

17. Arasaratnam S. Indians in Malaysia and Singapore. London: Oxford University Press for the Institute of Race Relations 1970. 214 p.

18. Arkin A. J. The Contribution of Indians in the South African Economy, 1860-1970. Durban: Institute for Social and Economic Research, University of Durban-Westville, 1981. 358 p

19. Assayag J., Benei V. At Home in Diaspora: South Asian Scholars and the West. New Delhi: Permanent Black, 2003 $207 \mathrm{p}$.

20. Azuma M. Sikh Diaspora in Japan. Routledge, 2018. 174 p.

21. Baumann M. Conceptualising Diaspora: The Preservation of Religious Identity in Foreign Parts, Exemplified by Hindu Communities Outside India // Temenos: Nordic Journal of Comparative Religion, 2012. Vol. 31. P. 19-35.

22. Bhachu P. The East African Sikh Diaspora: The British Case // Aspects of the South Asian Diaspora. New Delhi: Oxford University Press, 1991. P. 57-85.

23. Butler K. D. Defining Diaspora, Refining a Discourse // In Diaspora. 2001. Vol. 10. №2. P. 189-219

24. Chakraborty C. Shaming the Indian Diaspora, Asking for «Returns»: Swades // TOPIA: Canadian Journal of Cultural Studies, 2011. Vol. 26. P. 11-28.

25. Chakravarti N. R. The Indian Minority in Burma: The Rise and Decline of an Immigrant Community. London: Oxford University Press for the Institute of Race Relations, 1971. $214 \mathrm{p}$. 
26. Clarke C. South Asians overseas: migration and ethnicity. Cambridge: Cambridge University Press, 2010. 396 p.

27. Cohen R. Global Diasporas: An Introduction. London: Routledge, 2008. 240 p.

28. Dasgupta S. D. A Patchwork Shawl: Chronicles of South Asian Women in America. New Brunswick: Rutgers University Press, 1998. $239 \mathrm{p}$.

29. Dumitru S. Skilled Migration: Who Should Pay for What? A Critique of the Bhagwati Tax // Diversities. 2012. Vol. 14. № 1. P. 8-23.

30. Dusenbery V. A. A Sikh Diaspora // Nationand migration: the politics of space in the South Asian Diaspora. Philadelphia: University of Pennsylvania Press, 1995. P.17-42.

31. Fond Indian memories feed Anosh Irani's My Granny the GoldfishОшибка! Недопустимый объект гиперссылки. // The Georgia Straight. Vancouver. 2010. URL: https://www.straight.com/article-318887/vancouver/fond-indian-memoriesfeed-iranis-goldfish (Accessed: 20.05.2019).

32. Fuglerud Q. Life on the Outside: The Tamil Diaspora and Long-distance Nationalism. London: Pluto Press, 1999. 203 p.

33. Gottschlich P. The Indian Diaspora in the United States of America: An Emerging Political Force? // Indian Diaspora:

Retrospect and Prospect. New Delhi: Sage Publications, 2006. URL: https://sk.sagepub.com/books/tracing-an-indiandiaspora/n9.xml (Accessed: 12.05.2019).

34. Gupta A. The Indian Diaspora's Political Efforts in the United States // Observer Research Foundation. New Delhi, 2004. P. 1-21

35. Hawley M. Sikh Diaspora: Theory, Agency, and Experience (collection of essays). Calgary: BRILL, 2013. 438 p.

36. Helweg A.W. Sikhs in England: the development of a migrant community. Delhi: Oxford University Press, 1987. $282 \mathrm{p}$

37. Jain P.C. Indians Abroad: A Current Population Estimate // Economic and Political Weekly. 1982. Vol.17. № 8. P. 299304.

38. Jain P. C. Indians in South Africa: Political Economy of Race Relations. New Delhi: Kalinga Publications, 1999. 175 p. $90 \mathrm{p}$.

40. Jayaram N. The Dynamics of Language in Indian Diaspora // The Indian Diaspora: Dynamics of Migration, 2000. P. 147171.

41. Jayaram N. The Indian Diaspora: Dynamics of Migration. Delhi: Sage Publications. 2004. 255 p.

42. Jayaram N. The Metamorphosis of Caste Among Trinidad Hindus // Contributions to Indian Sociology. 2006. №40 (2). P. $143-173$

43. Khadria B. India Migration Report 2009: Past, Present, and the Future Outlook. International Migration and Diaspora

Studies Project, Zakir Hussain Centre for Educational Studies. New Delhi: Jawaharlal Nehru University, 2009. 147 p.

44. Know India Programme (Official website). URL: https://knowindia.gov.in/ (Accessed: 10.05.2019).

45. Kondapi C. Indians Overseas: 1838-1949. Madras: Oxford University Press. 1951. 550 p.

46. Lal B. V., Reeves P., Rai R. The encyclopedia of the Indian Diaspora. Honolulu: University of Hawaì Press, 2007. 416 p.

47. Lal V. India in the World: Hinduism, the Diaspora, and the Anxiety of Influence // Australian Religion Studies Review. 2003. Vol.16. №2. P. 19-37.

48. Lemon A. The political position of Indians in South Africa // South Asians overseas: migration and ethnicity. 1990. P. $131-163$

49. Leonard K. I. Locating Home: India's Hyderabadis Abroad. Redwood City: Stanford University Press, 2007. 402 p

50. Mishra V. Bollywood Cinema: Temples of Desire. London: Routledge, 2002. $296 \mathrm{p}$.

51. Mishra V. The Literature of the Indian Diaspora: Theorizing the Diasporic Imaginary. New Delhi: Routledge, 2007. 313 p

52. Morris H. S. The Indians in Uganda. Chicago: University of Chicago Press, 1968. $230 \mathrm{p}$.

53. Nath D. A History of Indians in Guyana. London: Published by the Author. 1970. 281 p.

54. Nayar K. E. The Sikh Diaspora in Vancouver: Three Generations Amid Tradition, Modernity, and Multiculturalism. Toronto: University of Toronto Press, 2004. $276 \mathrm{p}$.

55. Overseas Citizenship of India (Online OCI Services). URL: https://ociservices.gov.in/ (Accessed: 12.05.2019)

56. PM launches Pravasi Teerth Darshan Yojana // The Times of India (Jan 22, 2019). URL: https://timesofindia indiatimes com/india/pm-launches-pravasi-teerth-darshan-yojana/articleshow/67647538.cms (Accessed: 15.05.2019).

57. Puwar N., Raghuram P. (eds). South Asian Women in the Diaspora. New York: Berg, 2003. 264 p.

58. Rayaprol A. Negotiating Identities: Women in the Indian Diaspora. New Delhi: Oxford University Press, 1997. 165 p

59. Reddy P. C. Telugu Diaspora Through the Ages: From the Earliest Times. New Delhi: B.R. Publishing Corporation,

2017. 350 p.

60. Safran W. Diasporas in Modern Societies: Myths of Homeland and Return // In Diaspora. 1991. Vol.1. №1. P. 83-99.

61. Safran W., Sahoo A., Lal B.V. Transnational Migrations: The Indian Diaspora. New Delhi: Routledge, 2013. 211 p

62. Sahay A. Indian Diaspora in the United States: Brain Drain Or Gain? Lanham: Lexington Books, 2009. 262 p.

63. Speckmann J. D. Marriage and Kinship among the Indians in Surinam. Assen: Van Gorcum\&Co, 1965. $302 p$

64. Tatla D. S. The Sikh Diaspora. The Search for Statehood. London: UCL Press Limited, 2005. 293 p.

65. The Role of the Diaspora (A report to the Australian Government by Mr. Peter N. Varghese AO) // India Economic

Strategy to 2035. URL: https://dfat.gov.au/geo/india/ies/chapter-18.html (Accessed: 09.05.2019).

66. Therwath I. «Shining Indians»: Diaspora and Exemplarity in Bollywood // South Asia Multidisciplinary Academic Journal.

2010. URL: http://journals.openedition.org/samaj/3000 (Accessed: 20.05.2019).

67. Vertovec S. The Hindu Diaspora: Comparative Patterns. New Delhi: Routledge, 2013. 208 p. 


\section{Сведения об авторе}

Тонян Анаит Аслановна - аспирант кафедры зарубежной истории, политологии и международных отношений гуманитарного института Северо-Кавказского федерального университета, экскурсовод Музейно-выставочного комплекса «Россия - Моя история» (Ставрополь) / aslanovna27@mail.ru

\section{Information about the author}

Tonyan Anait - post-graduate student, Chair of foreing history, political sciences and international relations, Institute of Humanities, North Casucasus Federal University, Guide, Museum and Exhibition Complex «Russia My History» / aslanovna27@mail.ru 